\title{
Virus årsak til utmattelsessyndrom?
}

\author{
Et nylig oppdaget gammaretrovirus \\ ble påvist hos amerikanske pasienter \\ med kronisk utmattelsessyndrom, \\ men dette kunne ikke bekreftes hos \\ engelske pasienter.
}

En rekke mikroorganismer er foreslått å kunne utløse kronisk utmattelsessyndrom. Både kronisk utmattelsessyndrom og en type prostatakreft positiv for et nyoppdaget gammaretrovirus, xenotropisk leukemivirus (XMRV), har vært koblet til endringer i det antivirale enzymet RNase L. Amerikanske forskere har nå undersøkt om XMRV er til stede i perifere mononukleære blodceller fra pasienter med kronisk utmattelsessyndrom (1).

Hos 68 av 101 pasienter ble det påvist
DNA fra XMRV, sammenliknet med åtte av 218 hos friske kontrollpersoner. Det ble også vist at gammaretroviruset fra pasientene var infeksiøst, og at både celleassossiert og cellefri virusoverføring var mulig.

På bakgrunn av dette funnet undersøkte engelske forskere om pasienter i Storbritannia var bærere av XMRV (2). I en gruppe på 186 pasienter var forskerne imidlertid ikke i stand til å påvise XMRV eller et annet nært beslektet virus.

- Dette er nok en indikasjon på at årsakssammenhengene ved kronisk utmattelsessyndrom er komplekse og multifaktorielle, sier overlege Vegard Bruun Wyller ved Barneklinikken, Oslo universitetssykehus, Rikshospitalet.

- Det er allmenn enighet om at infeksjoner har betydning, men det er lite som tyder på at et spesifikt agens er hoved- ansvarlig for å utløse tilstanden. Det kan også tenkes at assosiasjonen mellom kronisk utmattelsessyndrom og visse mikroorganismer - inkludert XMRV - skyldes reaktivering av latente infeksjoner, altså at årsakspilen går motsatt vei, sier Wyller.

\section{Trine B. Haugen}

trine.b.haugen@hf.hio.no

Tidsskriftet

\section{Litteratur}

1. Lombardi VC, Ruscetti FW, Gupta JD al. Detection of an infectious retrovirus, XMRV, in blood cells of patients with chronic fatigue syndrome. Science 2009; 326: 585-9.

2. Erlwein $\mathrm{O}$, Kaye S, McClure MO et al. Failure to detect the novel retrovirus XMRV in chronic fatigue syndrome. PLoS ONE 2009; 5: e8519.

\section{Kunsten å brødfø ni milliarder mennesker}

Befolkningsvekst og økt forbruk medfører at det globale behovet for mat vil øke i minst 40 år til. Konkurranse om landområder, vann og energi og overbeskatning av fiskebestandene, i tillegg til nødvendige miljøtiltak, vil påvirke verdens matproduksjon. Klimaforandringer vil gi ytterligere utfordringer (Science 2010; 327: 812-8).

Vitenskapelig og teknologisk innovasjon av produksjonssystemene kan imidlertid føre til bedre utnyttelse og mer rettferdig fordeling. Ny teknologi kan bidra til et mer strategisk landbruk, der vann, næringsstoffer og pesticider tilføres på steder og til tider ut fra behov. Dermed optimaliseres innsats versus utbytte. Genmodifisering kan øke produksjonsgrensene og i nær fremtid også toleransen for tørke. Imidlertid er bruk av denne teknologien et tema som fortsatt vil være gjenstand for diskusjon.

\section{$\emptyset$ kt dødelighet ved alle typer spiseforstyrrelser}

Ved anoreksi er det rapportert økt mortalitet og økt selvmordsrisiko. I en ny studie vises det nå at dette gjelder alle typer spiseforstyrrelser (Am J Psychiatry 2009; 166: 1342-6).

Mortaliteten ble unders $ø$ kt hos pasienter som ble behandlet ved en akademisk klinikk i USA. $95 \%$ var kvinner. Mortaliteten var $4 \%$ ved anorexia nervosa, 3,9\% ved bulimia nervosa og $5,2 \%$ ved uspesifisert spiseforstyrrelse i oppfølgingsperioden (8-25 år).

\section{Behandling som øker risikoen for transplantat-mot-vert-sykdom?}

\section{Granulocyttkolonistimulerende fak- tor brukes etter allogen stamcelle- transplantasjon for å påskynde hema- topoetisk rekonstitusjon. Dette kan $\varnothing k e$ risikoen for transplantat-mot- vert-sykdom.}

I en musemodellstudie var dyrene som var blitt forbehandlet med helkroppsbestråling før transplantasjonen spesielt utsatt for transplantat-mot-vert-sykdom hvis de fikk granulocyttkolonistimulerende faktor (GCSF) (1). Økt uttrykk av G-CSF-reseptor på resipientens antigenpresenterende celler forsterket aktiveringen av transplanterte CD8-positive T-celler. Disse cellene er viktige i transplantat-mot-vert-reaksjonen. Transplanterte T-celler som på forhånd hadde vært eksponert for G-CSF, viste ikke en slik forsterket aktivering.

- Det er uvisst om disse funnene vil ha betydning for forekomst og alvorlighetsgrad av transplantat-mot-vert-sykdom, sier overlege Tobias Gedde-Dahl d.y. ved Seksjon for blodsykdommer, Oslo universitetssykehus, Rikshospitalet.

- Funnene passer med en registerstudie som viste økt risiko for transplantat-motvert-sykdom dersom man brukte G-CSF etter transplantasjonen med beinmarg som stamcellekilde, men ikke med GCSF-mobiliserte stamceller fra blod. Dette taler for at om man bruker helkroppsbestråling som

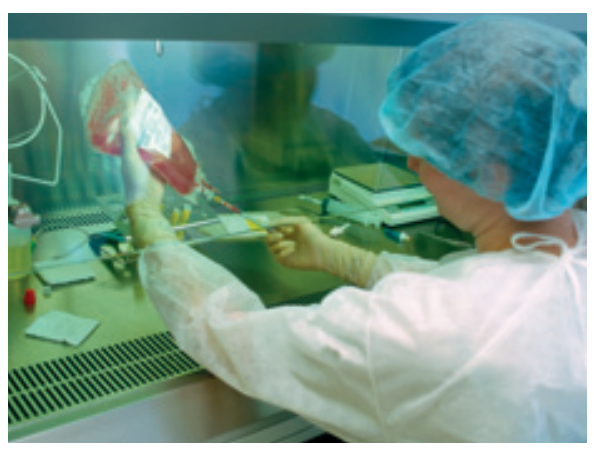

Illustrasjonsfoto $\odot$ BSIP/GV-Press/NordicPhotos

ledd i forbehandlingen, beinmarg som stamcellekilde og G-CSF den første tiden etter transplantasjonen, vil risikoen for transplantat-mot-vert-sykdom øke. Dette er en dyremodellstudie, men funnene bør has i mente ved den totale risikovurderingen knyttet til allogen stamcelletransplantasjon, sier Gedde-Dahl.

\section{Åslaug Helland}

aslaug.helland@gmail.com

Tidsskriftet

\section{Litteratur}

1. Morris ES, MacDonald KP, Kuns RD et al.

Induction of natural killer T cell-dependent alloreactivity by administration of granulocyte colonystimulating factor after bone marrow transplantation. Nat Med 2009: 15: 436-41. 